GLOBAL DEVELOPMENT AND ENVIRONMENT INSTITUTE

WORKING PAPER No. 10-05

\title{
The Macroeconomics of Development without Throughput Growth
}

\author{
Jonathan M. Harris
}

September 2010

Tufts University

Medford MA 02155, USA

$\underline{\text { http://ase.tufts.edu/gdae }}$ 


\begin{abstract}
:
Serious discussion has begun of policies to promote the goal of increasing wellbeing without material growth. Moving towards this goal requires a profound reorientation of macroeconomic theory. Importantly, the call by ecological economists to move away from traditional growth-oriented models comes at a moment when standard macroeconomics is in considerable turmoil. The financial crisis of 2008/2009 seriously undermined the basis for mainstream macroeconomics and brought renewed attention to various forms of Keynesian analysis and policy previously regarded as outdated.
\end{abstract}

There is a close complementarity between new Keynesian and ecological perspectives. While older Keynesian analysis was oriented towards promoting growth, a true Keynesian analysis of the relationship between investment and consumption does not depend on a growth orientation. What this analysis has in common with an ecological perspective is the rejection of market optimality assumed in classical models. Moving away from the neoclassical goal of inter-temporal utility maximization allows for different, pluralistic economic goals: full employment, provision of basic needs, social and infrastructure investment, and income equity. These goals are compatible with environmental preservation and resource sustainability, whereas indefinite growth is not. But they require a revitalization of the sphere of social investment, seriously neglected (indeed often omitted completely) in standard models.

Reintroducing this perspective allows the development of an economic theory suitable for the transition to a stable-population, low-carbon, resource-conserving global economy. The barriers to this transition are primarily political and institutional, not economic.

Specifically, an eco-Keynesian perspective emphasizes new macroeconomic categories including:

* human-capital-intensive services

* investment in energy-conserving capital

* investment in natural and human capital

The expansion of these categories provides a basis for growth in wellbeing without growth in throughput, while preserving full employment and economic stability. This paper explores some of the implications of this altered macroeconomic perspective for development in both the global "North" and "South". It is suggested that the problems following the global financial crisis cannot be resolved by a return to traditional growth patterns, and will require large-scale practical policies based on ecoKeynesianism. 


\title{
The Macroeconomics of Development without Throughput Growth
}

\author{
Jonathan M. Harris
}

\section{Introduction}

Serious discussion has begun of policies to promote the goal of increasing wellbeing without material growth. The idea of a steady-state macroeconomics was introduced into the modern economics conversation by Herman Daly (Daly, 1991a, 1991b), building on the fundamental analyses of Georgescu-Roegen (1971), although of course the origins of the concept go back much further, at least to J.S. Mill, ${ }^{1}$ with significant echoes in J.K. Galbraith ${ }^{2}$. In the growth model presented by R.M. Solow (1970), economic growth theoretically converges to a steady-state rate of growth based on the rate of growth of the labor force and technological progress - but would reach an absolute steady-state (with no economic growth) only if the rates of population growth and technological progress were both zero. Interestingly, Solow, the originator of modern growth theory, has recently stated:

"There is no reason at all why capitalism could not survive with slow or even no growth. I think it's perfectly possible that economic growth cannot go on at its current rate forever ... it is possible that the US and Europe will find that...either continued growth will be too destructive to the environment and they are too dependent on scarce natural resources, or that they would rather use increasing productivity in the form of leisure ... . There is nothing intrinsic in the system that says it cannot exist happily in a stationary state.”

-- Robert Solow ${ }^{3}$.

Peter Victor has introduced a model that shows scenarios for "managing without growth" in the Canadian economy. This interactive macroeconomic model indicates that with high social investment, a reduced work week, and a substantial carbon tax, a transition to low and then no growth can be accomplished simultaneously with declining poverty, unemployment, lower carbon emissions, and a reduced debt to GDP ratio (Victor, 2008). Tim Jackson suggests that "prosperity without growth" can be achieved by a shift from consumption to investment, with a specific investment focus on resource conservation, energy ${ }^{i}$ efficiency, clean technology, and ecosystem restoration (Jackson, 2009).

Similarly, Neva Goodwin and I have proposed a reorientation of consumption towards basic needs, health services, and education, and of productive technology towards resource-conserving investment (Harris and Goodwin, 2003). More specifically,

${ }^{1}$ See Book IV, Chapter 6 of Mill's Principles of Political Economy, on the Stationary State (Mill, 1994 [1848])

${ }^{2}$ See Galbraith, The Affluent Society (1958).

3 Robert Solow, quoted in Steven Stoll, "Fear of Fallowing: The Specter of a No-Growth World" Harper's Magazine, March 2008. 
I have advocated an ecologically-oriented revival of Keynesian theory, "deconstructing” the macroeconomic $\mathrm{C}+\mathrm{I}+\mathrm{G}+(\mathrm{X}-\mathrm{M})$ equation into categories representing energy- and resource-intensive sectors on the one hand and energy- and resource-conserving and human capital-intensive sectors on the other (Harris, 2007, 2009). A focus on environmentally-friendly technology and social investment then allows a revised Keynesian growth model, indicating the possibility of full employment without increased material consumption, or “throughput” in Herman Daly’s terminology (Daly, 1996).

Moving towards the goal of prosperity without material growth requires a profound restructuring of macroeconomic theory. Importantly, the call by ecological economists to move away from traditional growth-oriented models comes at a moment when standard macroeconomics is in considerable turmoil. The financial crisis of 20072009, with its legacy of continued high unemployment, seriously undermined the basis for mainstream macroeconomics and brought renewed attention to various forms of Keynesian analysis and policy previously regarded as outdated.

\section{The Current Crisis in Macroeconomics}

Paul Krugman, in an overview of the crisis of macroeconomics, points out that as recently as 2008 there was something approaching a consensus among macroeconomists (Krugman, 2009). Within the profession, most economists believed that there was a "broad convergence of vision," according to Olivier Blanchard of M.I.T., and that "the central problem of depression-prevention has been solved," according to Robert Lucas of the University of Chicago (Blanchard, 2008; Lucas; 2003). This confidence was based both on theoretical models that envisioned a self-equilibrating economy and a long period of relative stability and fairly steady economic growth from roughly 1985 to 2007 . As Krugman points out, events like the Asian macroeconomic crisis of 1997-8 made little impression on this U.S.-centered consensus. It is true that there were differences between New Keynesian economists, who recognized some imperfections in the process of economic adjustment, and New Classicals, whose theory of efficient markets essentially recognized none. But no crucial differences on policy arose while economic growth progressed smoothly.

The macroeconomic consensus was rudely interrupted by the Great Recession of 2007-9, and its aftermath of continued very high unemployment. Not only was the severity and depth of the recession unprecedented since the 1930's, the very aggressive fiscal and monetary policies used to counter it came straight out of the "old Keynesian" playbook, in contravention to everything that the new consensus - certainly the New Classical part of it - believed. New Keynesians adapted rapidly to the urgency of the policy needs, and some of them were in the forefront of formulating the emergency policies put into place by the Obama administration. But nothing in their theories had predicted or explained these dramatic developments. As Krugman describes it, this process of scrambling to catch up with reality has left macroeconomic theory in turmoil. 
According to Krugman, the first step back to reality is for economists to admit that "Keynesian economics remains the best framework we have for making sense of recessions and depressions" (Krugman, 2009). This would mean, at the least, extensive changes in the way formal macro theory is presented. In our text, Macroeconomics in Context, researchers at the Global Development and Environment Institute tried to develop the approach of taking Keynesian economics seriously as a fundamental framework for understanding the macro-economy (Goodwin et al., 2009). We also included sections on "Renewable Resources, Non-Renewable Resources, and Sustainability”, “Accounting for the Environment”, and "Macroeconomics and Ecological Sustainability" to emphasize that environmental issues are an essential part of macro. But these initial steps are only a beginning effort at the task that now confronts us - a complete reorientation of macroeconomic theory and policy.

There is a potential for close complementarity between a revived Keynesian and an ecological perspective. While older Keynesian analysis was oriented towards promoting growth, a true Keynesian analysis of the relationship between investment and consumption does not depend on a growth orientation. What this analysis has in common with an ecological perspective is the rejection of market optimality assumed in classical models. Moving away from the neoclassical goal of inter-temporal utility maximization allows for different, pluralistic economic goals: full employment, provision of basic needs, social and infrastructure investment, and income equity. These goals are compatible with environmental preservation and resource sustainability, whereas indefinite growth is not. But they require a revitalization of the sphere of social investment, seriously neglected (indeed often omitted completely) in standard models.

\section{A Reinterpretation of the Keynesian Vision}

As Krugman points out, Keynes' description of the situation at the onset of the Great Depression has a present-day resonance:

We have involved ourselves in a colossal muddle, having blundered in the control of a delicate machine, the working of which we do not understand. The result is that our possibilities of wealth may run to waste for a time - perhaps for a long time.

-- John Maynard Keynes ${ }^{4}$.

Keynes' "colossal muddle” seems to apply well to the confusion and dismay characterizing both economists and policy-makers in the face of the events of 2007-2009, and continues to ring true as we grapple with inadequate recovery and the possibility of a "double-dip" recession. Ecological economists might also recognize the concept of a blundering approach to a delicately balanced machine in a different sense, considering the widespread damage wrought on ecosystems that we only partially understand, as a result of unrestrained economic growth. But can the remedies suggested by Keynes -

${ }^{4}$ From J.M. Keynes (1930), “The Great Slump of 1930.” 
government intervention through fiscal and monetary policy to rebuild aggregate demand and economic confidence - also be reinterpreted in a more ecological sense?

It is worth considering the essential vision of Keynes concerning the causes of economic disruptions such as recession and depression, before looking at policy solutions. Keynes, of course, rejected the classical notion of an automatic tendency towards full employment based on price and wage adjustment. But the key element in his vision is not, as is frequently assumed, market imperfections or "sticky" prices. These may play a role. But the central point that Keynes emphasized, although it was lost on many of his later followers and exponents, was the essential instability of investment due to the uncertain connection between present and future. Theories of efficient markets depend on the idea of perfect information about market conditions - probably not possible even in the present. But perfect information about the future is clearly impossible. This is what gives rise to bubbles, boom and bust, and periods of irrational optimism or pessimism. Current investments are based on current prices, and expectations about the future. But expectations vary, and may be wildly wrong. The resulting variations in investment can generate self-reinforcing cycles in aggregate demand, leading to long periods of expansion or depression. Hence the clear need for government to stabilize the economy with countercyclical fiscal and monetary policy.

Here again there is an interesting parallel to a central issue in ecological economics. One of the key points about resource management is the inadequacy of market incentives for long-term resource conservation. Similarly, market mechanisms deal poorly with cumulative pollutants whose impacts build up over time. These resource and environmental issue have moved from being specific concerns about individual resources to macro-level issues of global climate change, fisheries collapse, groundwater depletion, etc. So it is evident that however well markets may deal with efficient allocation of resources in the short-term, they clearly fail to balance short-term (static) efficiency considerations with long-term (dynamic) efficiency. A clear government policy role is indicated to prevent resource overdraft and to sustain long-term resource and environmental balance.

If the current macroeconomic crisis forces a reassessment of the market-based, minimal government intervention approach that has characterized most mainstream economic theory, it seems necessary to take into account both the traditional Keynesian and the environmental critiques. A revised approach might be something like this:

Both inherent economic instability and the incompatibility between many market outcomes and environmental sustainability mean that national economies, and the world economy, are vulnerable to major economic fluctuations, and to degradation of the essential resource and environmental base for economic activity. This necessitates government intervention to stabilize economic systems and to preserve essential ecological functions. Monetary intervention is not enough. While central bank policy can to some extent mitigate economic fluctuations, it has crucial limitations. One limitation is the Keynesian "liquidity trap" - the inability of central banks to push interest rates below zero, or to ensure that additional monetary reserves will be deployed to create 
expanded aggregate demand. Another is the inability of monetary policy to create jobs directly, or to target interventions toward environmental investment. For these reasons, fiscal policy is essential, and needs to be focused specifically on the goals of full employment, social equity, and environmental sustainability. Monetary policy should be used both to enable these targeted fiscal interventions, and to promote traditional monetary goals of adequate liquidity and price stability.

As a description of the main principles of macroeconomic theory and policy, this clearly stands as rank heresy in terms of what up until recently has been the mainstream consensus. But, as noted, this consensus is now in serious question, and perhaps defunct. This creates a major opportunity for a new kind of macroeconomics to emerge - one that is "old" in that it returns to some traditional Keynesian principles, but "new" in that it incorporates the ecological realities of the twenty-first century. It provides an opportunity to address some of the major problems of the contemporary economy, including growing income and wealth inequality, inadequate infrastructure investment, fossil fuel dependence, and the adverse impacts of economic growth on the environment.

This revised approach does not provide a definitive answer to the question of whether or when a limit to macroeconomic growth - Daly's concept of "optimal macroeconomic scale" - may be required. It does, however, provide a framework to address this question as a central issue in macroeconomics. Daly first called for a move to a steady-state economy over a quarter of a century ago (Daly, 1973), but his perspective has never been taken seriously within mainstream macroeconomics. A revised macroeconomics will incorporate the possibility of a steady state, but there are many questions to be resolved about what this really means, and what a transition from current growth-oriented macro might look like.

\section{New Approaches to Macroeconomic Policy}

In previous articles, I have suggested that a new breakdown of the major sectors of aggregate demand is useful in thinking about alternatives to current economic growth patterns (Harris, 2009). Specifically, the three major sectors of consumption, investment, and government spending can be divided into subsectors representing material goods, services, resource-intensive and resource-conserving investment, and investment in human and natural capital. The idea is that we can then distinguish between those macroeconomic aggregates that should be strictly limited - resource-intensive consumption and investment, and energy-intensive infrastructure - and those that can expand over time without negative environmental consequences. The latter would include large areas of health, education, cultural activity, and resource- and energyconserving investment. My conclusion is that there is plenty of scope for growth in economic activity, concentrated in these categories, without growth in resource throughput, and with a significant decline in the most damaging throughput, that of carbon-intensive fuels. 
A major shift in the direction of "greener" economic growth will not, of course, come about without activist government policy. This is where the updated Keynesian view of economic policy is central. To some extent, the kind of transition to a lowcarbon, resource-conserving economy that I am suggesting could be accomplished through market incentives - "green taxes" and ecological subsidies aimed at internalizing environmental costs and promoting environmentally beneficial sectors. The combination of these taxes and subsidies could be revenue-neutral. But there is also a large necessary role for social investment, both in human capital and infrastructure. Fiscal policy plays the key role here. The discrediting of fiscal policy among economists has played a major role in enabling many of our current problems, from growing inequality to environmental degradation. If the "free market" is solely responsible for resource allocation, and government fiscal intervention is seen as ineffective or harmful, then these negative trends seem simply inevitable. Reversing this bias is essential, and the current disarray among mainstream economists provides an excellent opportunity to do so - at least in the realm of theory.

What about in the realm of practical policy? There are some recent examples of the effective uses of fiscal policy for environmental objectives. The Obama administration’s $\$ 787$ billion dollar stimulus package - the first clearly Keynesian expansionary fiscal policy in many years - included about $\$ 71$ billion for specifically “green” investments, together with $\$ 20$ billion in "green” tax incentives. Specific provisions directed spending on energy efficiency in Federal buildings and Department of Defense facilities ( $\$ 8.7$ billion); smart-grid infrastructure investment (\$11 billion); energy and conservation grants to state and local governments ( $\$ 6.3$ billion); weatherization assistance ( $\$ 5$ billion); energy efficiency and renewable energy research (2.5 billion); grants for advanced battery manufacturing ( $\$ 2$ billion); loan guarantees for wind and solar projects ( $\$ 6$ billion); public transit and high-speed rail ( $\$ 17.7$ billion); environmental cleanup (\$14.6 billion); and environmental research ( $\$ 6.6$ billion). According to a recent analysis by Alan Blinder and Mark Zandi, the aggressive Federal policy action including these "green" investments "probably averted what could have been called Great Depression 2.0 . . . without the government's response, GDP in 2010 would be about $11.5 \%$ lower, payroll employment would be less by some $81 \frac{1}{2}$ million jobs, and the nation would now be experiencing deflation."5

Unfortunately, fiscal stringency in Europe has had the opposite effect, resulting in cutbacks for solar and wind power subsidies. It remains to be seen whether the deflationary effects of this fiscal austerity will force some rethinking among European governments. Certainly a standard Keynesian analysis would suggest that at a time of high unemployment and near-zero inflation, deficit reduction should not be the prime concern. Prior to the onset of a misplaced doctrine of fiscal responsibility in Europe, Portugal had achieved an impressive government-led transition from fossil fuels towards renewable power, with the percentage of renewable supply in Portugal's grid up from 17

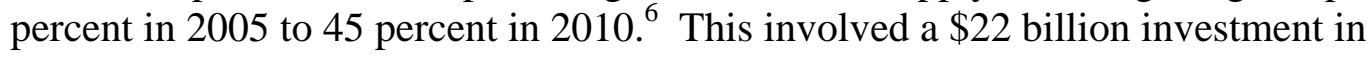
modernizing its electrical grid and developing wind and hydropower facilities. Portugal

${ }^{5}$ Blinder and Zandi, 2010.

6 “Portugal Gives Itself a Clean-Energy Makeover,” New York Times August 10, 2010. 
will recoup some of its investment through European Union carbon credits, and will save about \$2.3 billion a year on avoided natural gas imports. This example seems to indicate that major progress towards a sustainable energy system can be made in a relatively short period of time, without crippling costs or inflationary effects. Electricity prices are up about $15 \%$, partly as a result of the investment in renewables, but of course this is justifiable and even desirable from the point of view of internalizing environmental costs and creating incentives for conservation.

These examples just scratch the surface of what is possible with a more aggressive approach to promoting an environmental transition. With continuing high unemployment, programs that create jobs directly seem especially appropriate, either in the government sector (along the lines of President Roosevelt's Civilian Conservation Corps, an early environmental Keynesian undertaking) or through government programs carried out by private sector contractors. Continued timidity on the part of deficitconscious governments can only retard this transition, and prolong the period of high unemployment that we are now suffering.

\section{Green Growth or No Growth?}

One interpretation of the revised Keynesian perspective that I have outlined is that there is no need to worry about limits to economic growth. Rather, the issue is one of redefining economic growth in terms of energy-efficient, low-resource-throughput, service-oriented activities. After all, it is the unrestrained growth of physical production that Daly and others have warned is incompatible with Earth's ecosystems. Can we not grow the non-material aspects of consumption while limiting or reducing physical throughput of resources?

Peter Victor's recent work (Victor, 2010) gives an interesting perspective on this question. He distinguishes "green growth”, “brown growth”, "black growth”, and "green degrowth" in terms of two dimensions: traditionally measured GDP and greenhouse gas emissions per unit GDP. “Green growth' is growth in GDP with lower total greenhouse gas emissions. "Brown growth" is growth with declining GHG intensity but rising overall GHG emissions. "Black growth" is growth with rising GHG intensity. And "green degrowth" is decline in both GDP and GHG emissions. ${ }^{7}$ This formulation leaves open the possibility of a large wedge of "green growth", with the growth rate of GDP more than offset by the rate of decline in emissions intensity. A few countries, such as Britain and Sweden, have actually followed such a "green growth" path, while the U.S. is in the "brown growth" zone. ${ }^{8}$ Some developing countries, such as Indonesia and Brazil, have experienced "black growth" with increasing emissions intensity associated with GDP growth. ${ }^{9}$

\footnotetext{
${ }^{7}$ In theory, "black degrowth" is also possible, with declining GDP but GHG intensity increasing so fast that total emissions rise.

${ }^{8}$ See e.g. Sweden 2006: In Depth Energy Efficiency Review, http://www.encharter.org/index.php?id=121\&L=0

${ }^{9}$ Energy Information Administration (U.S.), Energy Information Annual 2006.
} 
Lest we get too excited about the possibilities for "green growth", Victor analyzes the carbon intensity reduction requirements for various growth paths needed to achieve targets such as the IPCC goal of atmospheric stabilization through an $80 \%$ reduction in greenhouse gas emissions by mid-century. At a zero growth rate for GDP, an $80 \%$ reduction target would of course require $80 \%$ reduction in intensity. But at a 3\% GDP growth rate, the same target would require a 95\% reduction in intensity, since GDP roughly quadruples over a 50-year period. Victor's point is that while there is significant potential for "green growth", if we are to achieve ambitious carbon-reduction targets economies would have to become virtually carbon-neutral to permit any growth at all. Whatever environmental target you choose, it is more difficult to achieve at faster growth rates - no matter how "green" the growth. In effect, whatever progress is achieved through greater energy and resource efficiency is undermined or completely negated by the effects of exponential growth.

One conclusion from this is that while economic growth is essential in the currently developing world, it can no longer be afforded in the industrialized countries. Programs to reduce carbon- and resource- intensity in those countries are essential, but even given an aggressive approach to a transition away from carbon, any economic growth, even "green” growth”, in already rich countries reduces the carbon budget available for the developing world. ${ }^{10}$

This logic is mathematically unassailable, provided we assume that increases in GDP and reductions in intensity are independent of each other. But this assumption conceals the economic realities involved in an economic transition to energy efficiency and renewables. Suppose, for example, that a particular economy implements a largescale program to replace coal-fired power plants with wind power. By all standard measures, this will involve a lot of economic activity, raising the investment component of GDP and increasing employment. But it need not involve any added consumption. The power that was formerly supplied by coal plants will now be supplied by wind (as in the case of Portugal cited above). So the country will have experienced economic growth with both a decrease in carbon intensity and an absolute decrease in carbon emissions. Once the investment program is completed, however, any growth in consumption will increase carbon emissions, though by a smaller amount than it would have previously (assuming that there is still some carbon-based power production in the system). Only if carbon-based fuels have been completely eliminated will it be possible to have increased consumption with zero net emissions increase.

This suggests that certain kinds of GDP growth (e.g. the growth in investment in wind power) are environmentally neutral or beneficial. A general increase in consumption is not. But it is also possible to conceive of kinds of consumption growth that are environmentally beneficial. Suppose, for example, that a family builds a fully solar, carbon-neutral house, ${ }^{11}$ and that the cost of this house is $20 \%$ greater than that of an

\footnotetext{
${ }^{10}$ For a perspective on the stringency of this global carbon budget and the tension between global North and South, see Baer, Athanasiou, and Kartha (2009).

${ }^{11}$ My colleague, Dr. William Moomaw, has built such a house for his retirement, in Western Massachusetts.
} 
ordinary house. By a standard GDP measure, the family's consumption is $20 \%$ greater than it would have been had they built an ordinary house. Yet this choice to consume "more" has led to lower carbon emissions. A similar logic might apply to, say, consuming organic food at a price premium. If the higher price of organic food is due primarily to more labor-intensive methods in production, then this additional GDP also represents increased employment - a Keynesian benefit in an economy operating at anything less than full employment.

So it appears that not all forms of economic growth are environmentally negative, and some may be beneficial. It is true, as Herman Daly has argued, that the "angelization" of GDP has its limits - once we have maximized energy efficiency, use of renewables, organic food production, etc., any increase in consumption must necessarily increase throughput (see Daly, 1973 and 1991b, quoted in Jackson, 2009, p. 130). It is also true that, broadly speaking, economic growth works against reduced throughput intensity, so that if we increase overall consumption while also improving resource efficiency, the net effect on the environment is less beneficial than if we had increased efficiency while holding consumption constant. Eventually the exponential effect of growth will overwhelm the gains. But nonetheless there are rather large opportunities for types of economic activity which involve a transition to more environmentally beneficial means of production.

\section{Towards a Theory of Economic Transition}

From a Keynesian point of view, it is crucial to exploit environmentally beneficial forms of economic growth. Some ecological economists may regard this assertion as an oxymoron. But I think the examples cited above show that it is not. This is also extremely important from a political point of view. Most people associate "economic growth" with jobs, income, and opportunity. Is it possible, economically and politically, to revise the concept so as to preserve the positive concepts associated with growth while eliminating negative effects on the environment?

The key to solving this conundrum is to think in terms of a global economic transition. We cannot continue indefinitely with exponential growth. But the transition to a steady-state economy must take place over along period of time. Suppose we think of two time periods, roughly the first and second halves of the twenty-first century. During the first of these periods, there are enormous opportunities for the kinds of beneficial investment and reorientation of the economy described in the simplified examples already given.

We can start with population. During the twentieth century, rising economic output was accompanied by steadily rising population, with the rate of population growth increasing during the second half of the century. This is an important element in standard models of economic growth. But now the rate of global population growth is slowing, and the absolute yearly increase has also begun to decline. Some nations have reached population stabilization, while virtually every nation has declining fertility rates. We can 
therefore foresee a stabilization of population by about mid-century. The absolute increase in global population yet to come is, of course, a huge environmental issue, and sound ecological economics suggests that every non-coercive policy that reduces fertility and overall population growth is beneficial. But in any case the transition to a stable global population is inevitable, and has begun. This in itself introduces a fundamental change in the nature of economic growth. It reduces the overall rate of growth, and it changes the nature of GDP in important ways.

A stabilizing population is a graying population. A larger cohort of older people requires more social security (or equivalent) payments and more expensive medical care, with fewer workers of prime working age to support them There is much hand-wringing about the budgetary implications of this trend. But from a Keynesian point of view it can be viewed as a positive development. It provides for plenty of employment in health care and other caring professions such as assisted living. These occupational opportunities are also, for the most part, in service industries with relatively low environmental impacts. A larger proportion of GDP in these sectors is environmentally beneficial, other things equal.

As noted above, there are great opportunities for investment and employment in the transition to renewable energy. These are available both in developed and developing nations. The strong commitment of China to renewable energy development indicates that this is no luxury for rich environmentalists. The Chinese rightly see it as the economic wave of the future, and they are determined to be in the forefront. This is good for them economically and good for the world environmentally. The Portuguese example suggests that nations at any level of development can profitably jump on this bandwagon, if their governments have the foresight to resist the short-term lure of low fossil fuel prices. To the extent that carbon trading regimes are established, there will be broad opportunities for poorer nations to participate in carbon storage schemes that are environmentally beneficial in terms of carbon reduction, forest preservation, soil reclamation, and employment generation.

A major focus of Keynesian economics is on social investment and infrastructure. Here too there are huge employment-generating opportunities. If the infrastructure is energy-efficient, and if social investment is directed towards education, health services, and the development of human capital, there will be no conflict between economic activity generated and environmental protection. Both carbon-neutral infrastructure and a shift towards human services are environmental positives. Note, however, that this will not happen through market mechanisms alone. It requires government leadership on the New Deal model, but on a global scale.

Another theme of Keynesian economic is job creation and income redistribution to benefit lower-income workers. This implies conscious policies to combat growing international and intranational inequity. But it is not a zero-sum game. Higher employment and higher wages and living standards for workers create greater global prosperity and a more stable basis for economic activity than a high dependence on consumption by the affluent. Rising wages (which we are beginning to see now in China, 
for example) also reduce the race-to-the bottom-aspect of international competition. Of course, there are significant environmental dangers associated with rising mass consumption. As far as possible, this should be channeled into consumption of more efficiently produced, less energy-hungry consumer goods. This again requires conscious government intervention. But the trend to development of a global middle class is hardly one which can, or morally should, be opposed.

During our "first period", roughly to 2050, economic growth is inevitable. The trick is to have environmental Keynesian policies that stabilize it and steer it towards a renewable energy transition and a human-capital, service-oriented economy. In the currently industrialized economies, growth should slow over this period, a trend that is already evident and will likely be reinforced by the aftereffects of recession of 2007-9. The economies of the Global South require vigorous growth, but this growth can be directly increasingly towards carbon-saving investment and energy efficiency.

How about the "second period", 2050 to 2100? Here the concept of a steadystate economy comes into its own. Population is likely to have stabilized, which is an essential element of steady-state economics. If the transitional period has been successful, middle-class standards of living will have been achieved by many, we can hope most, of the world's population, and the energy infrastructure shifted to a largely non-carbon based system, with the industrial infrastructure oriented towards high efficiency. Thriving sectors will exist in health care, education, and cultural activity, and - as Peter Victor has suggested - the work week can be reduced, at least in the richer nations, to spread the work and prevent unemployment (Victor, 2008). At this point it makes excellent sense to ask whether further progress requires increased consumption. If institutions have already been adjusted towards social investment and greater equity, the pressure for "economic growth" is likely to be much less. So economic theory can look forward to Mill's, or Daly's, steady-state, while helping to guide the essential transition that will make it possible.

\section{The Role of Economic Theory in Determining Public Policy}

What is the situation today in the world's "developed" nations? We suffer the highest unemployment since the Great Depression. People are desperate for a way forward. It is extremely unlikely that the standard model of a resumption of vigorous economic growth will occur. The economic, financial, demographic, and environmental changes that have already taken place are too great. Something new is needed.

A combination of Keynesian theory and ecological priorities offers a path that promises higher employment, greater equity, and a transition to a more sustainable economy. Eventually this will also lead to a steady-state economy, and clearly the most affluent nations must pioneer this transition. But the immediate task is to reinvigorate all economies using Keynesian methods oriented towards social and environmental goals. If these expansionary policies should be successful in returning economies to full employment, Keynesian fiscal policy would still be essential to the continuing transition. 
Reducing budget deficits would become an appropriate policy goal after full employment was achieved, but this would not preclude the types of transitional infrastructure investment discussed above. Rather, these investments would need to be financed with carbon and resource taxes, balanced by per-capita credits to preserve or increase income equity. ${ }^{12}$ Carbon taxes, or cap-and-trade with auction, could be used to raise revenue as needed, being adjusted to be revenue-neutral or net revenue-generating as fiscal conditions required.

The continuing problems following in the wake of the global financial crisis cannot be resolved by a return to traditional growth patterns, but appealing to a nogrowth scenario will not meet the case either. Large-scale practical policies based on eco-Keynesianism provide a way forward, and can initiate a transition to a stabilized, low-carbon, low-throughput world economy.

Jonathan Harris is Director of the Theory and Education Program at the Global Development And Environment Institute. He holds a Ph.D. from Boston University. Inquiries can be sent to Jonathan.Harris@tufts.edu

${ }^{12}$ See Boyce and Riddle (2009) for an exposition of “cap and dividend” policies to reduce carbon and promote income equity. 


\section{REFERENCES}

Baer, P. T. Athanasiou, and S. Kartha (2009), “The Right to Development in a ClimateConstrained World," Chapter 4 in Harris, Jonathan M., and Neva R. Goodwin (eds), Twenty-First Century Macroeconomics: Responding to the Climate Challenge, Cheltenham, U.K. and Northampton, MA: Edward Elgar.

Boyce, James K., and Matthew Riddle (2009), "Cap and Dividend: How to Curb Global Warming while Promoting Income Equity,” Chapter 4 in Harris and Goodwin, op. cit.

Blanchard, Olivier J. (2008), “The State of Macro,” National Bureau of Economic Research Working Paper No W14259, August.

Blinder, Alan S. and Mark Zandi (2010), "How the Great Recession was Brought to an End,"

http://www.economy.com/mark-zandi/documents/End-of-Great-Recession.pdf

Daly, Herman E., ed. (1973), Toward a Steady-State Economy. San Francisco: W.H. Freeman.

Daly, Herman E. (1991a), "Elements of Environmental Macroeconomics,” Chapter 3 in Robert Costanza (ed.), Ecological Economics: The Science and Management of Sustainability, New York: Columbia University Press.

Daly, Herman E. (1991b), Steady-State Economics. Washington, D.C.: Island Press.

Daly, Herman E. (1996), Beyond Growth: The Economic of Sustainable Development, Boston: Beacon Press.

Galbraith, John Kenneth (1958). The Affluent Society, Boston: Houghton Mifflin. Georgescu-Roegen, Nicholas (1971). The Entropy Law and the Economic Process. Cambridge, Mass: Harvard University Press.

Goodwin, Neva, Julie A. Nelson, and Jonathan M. Harris (2009), Macroeconomics in Context, Armonk. N.Y. and London, England: M.E. Sharpe.

Harris, Jonathan M. (2007), "Reorienting Macroeconomic Theory towards Environmental Sustainability,” Chapter 2 in John M. Gowdy and John D. Erickson (eds), Frontiers in Ecological Economic Theory and Application. Cheltenham, U.K. and Northampton, MA: Edward Elgar.

Harris, Jonathan M. (2009), "Ecological Macroeconomics: Consumption, Investment, and Climate Change,” Chapter 8 in Harris, Jonathan M., and Neva R. Goodwin (eds), Twenty-First Century Macroeconomics: Responding to the Climate Challenge, Cheltenham, U.K. and Northampton, MA: Edward Elgar. Also available at http://www.ase.tufts.edu/gdae/Pubs/wp/0802EcologMacroEconJuly08.pdf

Harris, Jonathan M. and Neva R. Goodwin (2003), "Reconciling Growth and Environment,” Chapter 11 in Harris, Jonathan M., and Neva R. Goodwin (eds), New Thinking in Macroeconomics, Cheltenham, U.K. and Northampton, MA: Edward Elgar.

Jackson, Tim (2009), Prosperity without Growth: Economics for a Finite Planet, London: Earthscan Publishing. 
Keynes, John Maynard (1930), “The Great Slump of 1930,” London: The Nation and Athenaeum, December 20 and 27, 1930.

http://www.ritholtz.com/blog/2008/12/the-great-slump-of-1930/

Krugman, Paul (2009), “How Did Economists Get it so Wrong?” New York Times Sept 2.

Lucas, Robert (2003), “Macroeconomic Priorities,” American Economic Review 93 (1), $1-14$.

Mill, John Stuart (1994), Principles of Political Economy: and Chapters on Socialism; edited with an introduction by Jonathan Riley. Oxford and New York: Oxford University Press [original publication 1848].

Solow, Robert M (1970), Growth theory: an exposition. New York, Oxford University Press.

Victor, Peter A. (2008). Managing Without Growth: Slower by Design, Not Disaster, Cheltenham, U.K. and Northampton, MA: Edward Elgar.

Victor, Peter A. (2010) "Macroeconomics for Sustainability”, Presentation at Tufts University, February $16^{\text {th }}$. (Contact author at York University, Toronto, Canada). 